\title{
Co-adaptation of Apis cerana Fabr. and Varroa jacobsoni Oud.
}

\author{
Werner Rath \\ Department of Horticulture, Faculty of Agricultural Production, \\ Maejo University, Sansai, Chiang Mai, Thailand
}

(Received 20 August 1998; accepted 11 February 1999)

\begin{abstract}
The research on bee and mite biology over the past 20 years has uncovered numerous details of the $A$. cerana- $V$. jacobsoni co-adaptation which are systematically summarized here. A. cerana acquired a high degree of hygienic efficiency with a differentiated set of behavioural traits that we describe in this review in a broad sense to include grooming of mites by adult bees, uncapping and removal of infested brood and entombing of infested brood. Approximately $20 \%$ of the reproducing mite population can be eliminated by entombing of lethally parasitized drone pupae. In their equally effective infesting behaviour the parasites explore the most suitable adult and larval host individuals for safe phoretic positions, the favourable caste and suitable age. A. cerana compel $V$. jacobsoni to reproduce exclusively on drone brood hosts. This limited reproduction, in combination with characteristics of the population dynamics of the host, are key factors which limit mite populations to tolerable levels. (C) Inra/DIB/AGIB/Elsevier, Paris
\end{abstract}

Apis cerana / Varroa jacobsoni / co-adaptation

\section{INTRODUCTION}

Varroa jacobsoni Oudemans (Acari: Varroidae) females were first collected by Jacobson from its host, the Asian honeybee Apis cerana Fabricius, in the year 1904 in Java, Indonesia, and were subsequently described by the zoologist Oudemans. The bee parasite received increased attention by scientists only after it became a major pest on its acquired host, Apis mellifera L., in Europe. The early research on the life cycle, biology and impacts of $V$. jacobsoni was almost exclusively conducted on the new host $A$. mellifera. However, it appeared that a profound understanding of $V$. jacobsoni and the parasite-host relations had to be

E-mail: rath@chiangmai.a-net.net.th 
based on the original relationship between $A$. cerana and $V$. jacobsoni. While the early reports from Koeniger et al. [21, 22] attracted attention to the original host, the two publications of Peng et al. in 1987 [28, 29] on the successful grooming behaviour of A. cerana worker bees were received with great excitement. The research of Peng [28] nurtured the hope of finding new ways to control $V$. jacobsoni on A. mellifera. Even as the quantifications of Peng et al. [28] are revised by more recent research $[4,10,17$, 30], this first publication on the interaction between $V$. jacobsoni and $A$. cerana is still substantial and frequently cited.

The research on the co-adaptations between $A$. cerana and $V$. jacobsoni over the past 18 years remains modest compared to the extensive attention to $V$. jacobsoni on A. mellifera, e.g. as reviewed in 1994 by Milani [26]. Still lacking are data on the population dynamics of $A$. cerana and $V$. jacobsoni in their natural area of distribution, and data on the reproductive biology of $V$. jacobsoni on drone brood of $A$. cerana. Many of the well-studied aspects of the mite behaviour in $A$. mellifera hosts are almost unknown from the original host $A$. cerana; e.g. the cognitive abilities and stress-related behaviour of $A$. cerana, and the behaviour in brood cells, reproductive cycles, phoretic choice and dispersal of the mites.

Interspecific co-adaptation is a theoretical concept that describes the phenomena of a mutual adaptation of two species. The interpretation of observable phenomena as co-adaptation is closely connected to the concept of co-evolution which implies the assumption that the ancestors of $A$. cerana and $V$. jacobsoni exerted selective forces on one another [34]. The following sections will summarize host and parasite traits that mutually influence their respective fitness and accordingly can be considered as coadaptive traits. The current knowledge on the relationship between $A$. ceranae and $V$. jacobsoni is grouped here under three categories: 1) hygienic traits versus infesting traits; 2) population-dynamic aspects; and 3) physiological aspects. The use of the word 'hygienic' is used here in the broad sense to include grooming behaviour, the uncapping and removal of parasitized brood, and the entombing of mites in cells, as opposed to Rothenbuhler's use of 'hygienic behaviour' to describe solely the uncapping and removal of diseased brood [37]).

\section{HYGIENIC TRAITS OF}

A. CERANA VERSUS INFESTING TRAITS OF $V$. JACOBSONI

\subsection{The senses of bees and mites}

It is obvious that bees and mites must have elaborate senses to perceive each other's presence in different places and occasions. V. jacobsoni depends on specific senses to locate its host, to move to phoretically safe places on adult bees $[14,32]$, to find phoretic feeding places and even to distinguish between adult bees of different ages and physiologic states (on A. mellifera: $[6,7$, 241). The sensory capabilities of $V$. jacobsoni provide it with information that directs its behaviour to the correct worker or drone brood host which allows optimum timing of reproduction in A. cerana colonies. Apart from the sensory capabilities, the mites interact with each other during feeding on adult bees and in brood cells (on A. mellifera: [15]). Adult female mites are able to recognize host bees in close proximity, and they frequently react by jumping rapidly to attach themselves phoretically to their host. However, apart from some experimental evidence on $A$. mellifera hosts and assumptions deduced from general observations, there is little information on the neurophysiology of $V$. jacobsoni, the qualities of its senses and the stimuli that regulate its behaviour to safe phoresy, successful dispersal and effective reproduction on $A$. cerana hosts.

A. cerana must also have specific senses to detect mites on its body or in brood cells. These specific senses are a prerequisite to 
pursuing the hygienic actions of grooming, the uncapping of cells and the removal of infested brood. Most of the neurobiology of the bees in relation to their perception of the mites is obscure and several observations are not congruent. For example, it is common to observe exposed $V$. jacobsoni females on the thorax of $A$. cerana workers without any grooming reaction by the bees. Nestmates may even touch the exposed phoretic mites with their antenna or mouth parts without any further reaction to the parasite. Additionally A. cerana are not disturbed at all by certain non-parasitic phoretic mites that are almost as large as $V$. jacobsoni [12]. In southern Thailand, individual A. cerana workers were found with more than ten mites of the non-parasitic pollen-feeding Neocypholaelaps sp., and the bees did not show any grooming response (pers. obs.). On the other hand, the bees are disturbed and react by self grooming or by performing grooming dances when $V$. jacobsoni leave phoretically safe positions and move around on their hosts.

Some investigations suggested that olfactory senses are important in mite detection, e.g. A. cerana were found to be more sensitive in the detection of experimental mites that originated from another host colony ([10,36], conc. adhering scents: [27]. It is not known how bees sense that certain sealed brood cells are infested with $V$. jacobsoni, or contaminated with artificially introduced particles $[30,36]$. This remarkable sense, which also occurs in A. mellifera, induces the uncapping and removal of microbial-infested and dead sealed brood $[37,41,42]$. In an early investigation on the abilities of $A$. mellifera to detect sealed worker brood infested with American foulbrood, Schulz-Langer [40] found that bees detected and uncapped such infected cells rapidly when the volume of the cell contents was altered rather than when the cells contained strong smelling substances. The researcher concluded that physical stimuli such as responses to the volume of the cells may play a greater role in the detection of diseased brood than olfactory stimuli. It is also uncertain whether nursing bees perceive qualitative information on the condition of sealed bee brood via pheromone substances, which might enable the bees to recognize healthy or infested, parasitized or dead pupae, and consequently tolerate them or reject them.

\subsection{Grooming of $V$. jacobsoni by A. cerana}

A. cerana worker bees perform a highly differentiated set of behavioural traits that can be summarized as 'grooming', 'uncapping', 'removing' and 'entombing' $[19,21$, $22,28,29,33]$.

The grooming action of $A$. cerana toward phoretic $V$. jacobsoni received much attention following a research report by Peng at al. [28]. The researchers observed that A. cerana bees groomed themselves and also performed grooming dances to recruit individual or several nestmates to engage in social grooming. During self grooming, A. cerana bees brush different parts of their body. In social grooming, the nestmates touch the thorax, propodeum and abdomen of the infested bee with their antenna, front legs and mandibula. The action of grooming is not specifically directed at the phoretic mite; rather, it appears that distinct areas are automatically searched [13, 32]. The grooming activity may cause the parasite to leave the host or the bees may succeed in damaging the mite with their mandibula. Most of the damage that $A$. cerana bees inflict on $V$. jacobsoni occurs on parts of the legs $[10,17,30]$.

Table I compares the results from four experimental investigations on the grooming activity of $A$. cerana. The success rates of chasing the mites from their host bee are reported to range from 61.7 to $99.6 \%$, while the success rate of actually killing the mites ranged from 52 to $61 \%$ (table I). The quantification of grooming success rates and the results on the detection of mites in sealed 
Table I. Comparative results of four investigations on the grooming success of A. cerana.

\begin{tabular}{lcccc}
\hline Author & \multicolumn{2}{c}{ Grooming success of A. cerana } & & Mite source \\
\cline { 2 - 4 } & Chased & Dead & Damaged & \\
\hline Peng [27] & $99.6 \% / 2 \mathrm{~h}$ & & $73 \%$ & A. mellifera, brood/phoretic? \\
Büchler [10] & $\begin{array}{l}64.7 \% / 5 \mathrm{~min} \\
\end{array}$ & & & A. cerana, phoretic mites \\
& $92.3 \% / 5 \mathrm{~min}$ & & & A. mellifera, phoretic mites \\
Fries [17] & & $52 \% / 6 \mathrm{~h}$ & $29 \%$ & A. mellifera, phoretic \\
Rath [29] & & $61.7 \% / 48 \mathrm{~h}$ & $83 \%$ & A. mellifera, phoretic \\
\hline
\end{tabular}

brood are influenced by the source of the mites [10,36]. Mites that originated from A. mellifera colonies were detected by the alien scents of the mites, and mites that were collected from brood cells were not fit for phoresy [30]. According to Peng et al. [28] the ability to groom mites indicates that $A$. cerana "evolved both a physiological and a behavioural adaptation to the parasitism of $V$. jacobsoni". These researchers suggested that the bees sense the mites because of "irritation ... caused by salivary components injected by the mouthparts of the mites during feeding". In fact, $A$. cerana workers react most intensively to mites that just arrive and move on their body, and the bees groom less or not at all when mites stay calmly in their phoretic feeding positions in lateral intersternite folds (pers. obs.).

In the studies cited in table I, it was rarely pointed out that the experimental results on the grooming success rate would leave virtually no chance for survival for the parasites [17]. In contrast to the experimental results on grooming success rates [28], calculations derived from a model of the population dynamics of $V$. jacobsoni by Fries et al. [16] indicate that the grooming of A. cerana workers would cause a daily mite mortality of $1 \%$, and restrict the number of reproductive cycles of mother mites to 0.75 cycles. The daily mortality of $1 \%$ would reduce an initial mite population of ten $V$. jacobsoni to five mites only after 70 days.
The parameter on reproductive cycles, as assumed by Fries et al. [16] for A. cerana, is not appropriate since the authors based their calculations on rates of drone rearing and seasonal production of drones in temperate A. mellifera colonies. The population dynamics of drones in A. cerana colonies, however, differ considerably from $A$. mellifera (see section 3 ).

\subsection{The phoretic strategy of $V$. jacobsoni}

$V$. jacobsoni has a very peculiar body shape and associated traits that enable the mite to evade the bees' grooming attacks [25]. The adult $V$. jacobsoni females have an elliptical and concave shaped dorsal shield of approximately $1.5 \times 1 \mathrm{~mm}$. The concave dorsum is matched by a convex ventral side, which permits a close fit to the rounded surfaces of the host body. This morphology is of foremost importance in the avoidance of the bees' grooming attempts, and may be a physical adaptation which enabled the Varroidae to be phoretic, in contrast to the laelapid mites (see below). A. cerana workers can open their mandibula to approximately $2 \mathrm{~mm}$ (in northern Thailand); thus, the size of the dorsal shield of $V$. jacobsoni is less protective than the function of the concave-convex body shape. Grooming workers have no chance to grab the parasite once an adult female $V$. jacobsoni reaches a posi- 
tion on the host where its concave ventrum fits closely to the rounded bee body. In this respect, the peculiar shape of $V$. jacobsoni is a morphological adaptation to the bees' intensive grooming. The only opportunity for $A$. cerana workers to catch a mite is to bite it from the side, with one mandibula on the dorsal and the other on the ventral side of the mite. Therefore, the space between the edge of the mite dorsal shield and the host body surface is of crucial importance. The lanceolate lateral and posterior setae of the Varroidae, which are especially prominent in the genus Euvaroa sp., are structures which support the closing of the gap between the mite dorsal shield and the host surface.

Two observations may underline the significance of mite morphology to grooming success. First, female $V$. jacobsoni change the convexity of their ventrum into a flat or concave condition when they enter the reproductive stage. Usually such gravid mites stay in brood cells and are not subjected to grooming by bees. It was observed frequently that gravid mites which were released onto A. cerana workers were caught and damaged quickly by grooming workers because the mites had lost their close fit to the host body surface when the gap between the edge of the dorsal shield and the host surface was widened. Under natural conditions, gravid mites that leave brood after the bees uncapped the cell $[30,36]$ most likely become victims of grooming bees. The second observation concerns the accidental occurrence of Tropilaelaps clareae mites in A. cerana colonies [13, 49]. Although $T$. clareae comes into close contact with $A$. cerana it survives only on Apis dorsata and Apis mellifera hosts [13]. T. clareae have a phoretic strategy which is different from the slow moving, "closefit' approach of the Varroidae. These laelapid mites escape grooming attempts by very rapid movements on the host. Their elongated body facilitates fast forward movements but at the same time offers a narrow and protruding dorsum which $A$. cerana obviously finds convenient to grasp.
The 'rapid escape' strategy seems to work well for Tropilaelaps ssp. on A. dorsata and A. mellifera but fails completely when confronted with the grooming skills of $A$. cerana [49]. Likewise, the Varroidae never established themselves on $A$. dorsata hosts.

\subsection{Preferences for phoretic positions}

$V$. jacobsoni mites prefer certain phoretic positions on $A$. cerana, where they are safe from the hosts' grooming attempts and where they encounter a chance to feed. The bees groom only certain body areas, so it seems that the mites are indirectly guided to the safe positions by the grooming attempts of the bees. On $A$. cerana workers, $87 \%$ of $V$. jacobsoni choose phoretic positions between the second and third lateral tergites (anatomically the first abdominal segment is included in the propodaeum) [32]. On A. cerana drones, this preference was even more restricted to the second lateral intertergit on the left side. The left-sided preference for the phoretic position was very consistent in 52 out of 54 cases and there is at present no explanation for this phenomenon ([14, 30,32], for A. mellifera: [6]). It seems that $A$. cerana drones do not practice self grooming nor do they participate in social grooming, accordingly a higher percentage of mites can be found in exposed positions on the thorax or abdomen of drones when compared to workers [20, 32]. At the colony level, V. jacobsoni populations were found on approximately $75 \%$ on the worker bees and approximately $25 \%$ on drones. Cage experiments revealed a similar distribution pattern [30].

\subsection{Uncapping, removal, and entombing behaviour of $A$. cerana}

A. cerana are able to detect parasitized capped worker brood. Their first reaction consists in the uncapping of the invaded 
Table II. Emergence rate of $A$. cerana drones that were artificially infested with 1, 2 and $3 \mathrm{~V}$. jacobsoni females within $6 \mathrm{~h}$ after wax capping. Mite source: ex A. mellifera brood.

\begin{tabular}{lccc}
\hline $\begin{array}{l}\text { Emergence rate and } \\
\text { host condition }\end{array}$ & \multicolumn{3}{c}{ A. cerana drone brood artificially infested with: } \\
\cline { 2 - 4 } & 3 mites & 2 mites & 1 mite \\
\hline $\begin{array}{l}\text { Drones, emerged normal (n) } \\
\text { Drones, not emerged: }\end{array}$ & 3 & 6 & 19 \\
$\quad$ dead (n) & 5 & 5 & 2 \\
$\quad$ deformed (n) & 12 & 6 & 0 \\
$\quad$ normal (n) & 1 & 6 & 0 \\
Total drones, not emerged $(\%)$ & $85.7 \%$ & $71.4 \%$ & $9.5 \%$ \\
\hline
\end{tabular}

worker cells, and is probably followed by a closer inspection of the brood. If the mites leave the opened cell, the workers accept the brood as healthy and re-seal the cell [31, $33,36]$. If the mites stay in the brood cell, the bees cannibalize or remove the worker brood. This uncapping and removal behaviour is not a specific adaptation against $V$. jacobsoni, it is a general hygienic trait because the bees also react by uncapping and removing the brood when the brood cells are inoculated with particles of different materials $[33,36]$ or when the larvae are suffering from microbial infestations [37, 41]. Rosenkranz et al. [36] assumed that the bees detect the specific odour that adheres to the mites, or that the bees are sensitive to vibrations in the brood cells. Although the particles (chitin from $A$. cerana) used in the experiments of Rosenkranz et al. [36] did not carry $V$. jacobsoni odours, they were still recognized. It might be that the bees react to metabolic products of the worker brood, such as brood pheromones, that are released in varying quantities in relation to the health condition of the brood $[31,48]$.

When freeze-killed sections of worker brood were offered to an A. cerana colony in Thailand, the bees repeatedly uncapped and removed all dead worker brood within $48 \mathrm{~h}$ $[30,31]$. In the same experiment, the bees did not remove the freeze-killed drone brood (less than $10 \%$ removal after 13 days). Sim- ilarly, the bees did not react to mite-infested dead drone brood. The $A$. cerana workers left the dead drone brood capped, thus entombing the parasites and any brood disease $[19,22,23,30]$. Therefore, the bees may use two strategies: uncapping + removal and entombing. Both strategies are potentially successful; uncapping + removal eliminates infesting agents from the hive, and entombing seals off these agents [42]. A. cerana drones are especially sensitive to invasion by two or more $V$. jacobsoni. In experiments in which brood cells were experimentally infested with mites, only 28.6 and $14.3 \%$ of drones eclosed when two mites and three mites, respectively, invaded the cell $[30,32]$ (table $I I)$. More than half of such multiple-infested drones did not show any visible signs of an arrested or otherwise handicapped development. Instead, it seemed that they were not able to mobilize sufficient energy to open their own hard cocoon caps. In the natural situation, A. cerana bees are not inclined to remove dead drone brood rapidly. Mites as well as other pests that affect the dead drone pupa are entombed. Koeniger et al. [23] reported accumulations of 10-28 dead $V$. jacobsoni per cell together with the dead drone pupa. These cells were invaded by two to five mother mites, considering that one invading mother $V$. jacobsoni produced four offspring $[5,39]$. 
Multiple infestation of $A$. cerana drone cells is not a rare event. Boot et al. [5] found that $19.9-25.8 \%$ of infested $A$. cerana drone cells were invaded by two mites and 6.6-9.0\% were invaded by three $V$. jacobsoni (data collected from North and South Vietnam, respectively). By combining the data on eclosure rates of multiple-infested cells [30] and the frequency of multiple A. cerana drone cell infestations [5], it can be derived that out of 100 reproducing V. jacobsoni, 19-26 mites are killed by entombing, up to one quarter of the reproducing mite population. Although the multiple invasion of cells might facilitate genetic variation of $V$. jacobsoni by the increased chance for interbreeding [18], it imposes a significant limiting effect on the population growth by the resulting risk of entombing. Entombing has scarcely been researched, but it may be the most effective limitation of $V$.jacobsoni population growth. The aggregated distribution of mites in drone brood cells is most likely a dynamic function of the correlation between the amount of invasible cells and the number of reproductive mites at a given time. Multiple cell invasions and subsequent entombing of these infested drones are most prominent in $A$. cerana colonies with small amounts of drone brood and large $V$. jacobsoni populations.

The drone cell caps of $A$. cerana are a very unique structure whose biological significance, function and relation to $V$. jacobsoni are still unexplained $[19,20,31]$. The hard, funnel-like drone cell cap is part of the larval cocoon. The original wax cap of the drone cell is usually removed by the worker bees after the completion of the cocoon cap. The cocoon cap has an elevated central hole which is necessary for the exchange of respiration gases $[30,31]$. One experiment still requires interpretation in relation to the uncapping and removal behaviour. When the cell caps from healthy worker and drone brood in prepupal stage were experimentally removed, the worker bees accepted the worker brood and resealed it with a wax cap, but they rejected and removed the drone brood $[30,31]$. Is the drone cocoon cap a protective device? What are the ethological reasons for the rejection of capless drone brood, and is there an evolutionary connection to the parasitic mites? Hadisoesilo and Otis [19] recently discovered that a close relative of $A$. cerana in Papua New Guinea, Apis nigrocincta, has a soft wax cap only; i.e. the hard cocoon cap is missing completely. However, this observation needs further investigation as related details on the mite parasites in Apis nigrocincta presently are missing.

\subsection{Brood cell invasion strategies of $V$. jacobsoni}

During the invasion of $A$. cerana drone cells, the mites are exposed and subjected to detection by nurse bees. $V$. jacobsoni females squeeze themselves into the narrow gap between the host larva and the cell wall. The convex dorsal shield, which is facing the rounded cell wall, appears to be an advantageous morphological adaptation. In comparison, we observed the laelapid mite, Tropilaelaps clareae, staying on top of their host larva during cell invasion until the nurse bees completed the wax cap and the bee larva began cocoon-spinning movements. When the female $V$. jacobsoni reach the cell bottom of $A$. cerana drone cells, they regularly submerge themselves in the remains of liquid larval food $[30,32]$. In this submerged stage, the peritremes of the mite protrude visibly from the liquid food, but it is not clear which actual function should be attributed to the peritremes [8]. Based on their comparison of the peritremes of $V$. jacobsoni and Tropilaelaps spp., Bruce et al. [8] suggested that the adaptive hypotheses of the peritremes should be reviewed with caution.

When $V$. jacobsoni females come into contact with the bee larval food, they stop all active movements and rest in a state of akinesis until all the bee food is removed by the feeding larvae. The mites usually recover 
before the bee larvae spin their cocoon; however, in rare cases, dead mites can be encountered fixed to the cell bottom by cocoon threads. The akinesis stage, which can be experimentally triggered [30, 32], helps the mite to reduce oxygen consumption while submerged and it also reduces the chances that nurse bees recognize movements of mites in the infested cells. It is not clear whether the mites submerge themselves in larval food purposely or accidentally, but apparently the mites are well adapted to this unusual condition. The mite behaviour of proceeding to the bottom of the host brood cells and submerging themselves in the remains of the larval food can be interpreted as a counter-strategy to the well-developed removal behaviour of the adult bees.

\section{A. CERANA POPULATION DYNAMICS}

A. cerana colonies inhabit a wide range of climates ranging from arid to temperate subtropical and tropical regions [38]. Accordingly, the population dynamics of $A$. cerana colonies may vary considerably. The periods and amounts of drone brood rearing are of foremost importance in the coadaptation between $A$. cerana and $V$. jacobsoni because the reproduction of the mites is restricted to drone brood owing to the mite's infertility in A. cerana worker brood cells, and the removal of infested brood by worker bees $([1,5,21,29,33,36,47]$, see also table III). However, only a few published data on drone brood rearing seasons and cycles for A. cerana are available. In Japan, Sasaki [39] reported a distinctive drone brood season of 3 months from mid March to mid June for A. cerana japonica. The corresponding time for $A$. mellifera drone brood rearing in the same region in Japan was 3 months longer than for $A$. cerana. In the Chiangmai region of northern Thailand, A. cerana colonies had one or two drone brood rearing cycles per year with periods of on average $59.5( \pm 33.4)$ days and an average drone production of 30 drones per colony per day $[30,32]$. The peak number of sealed drone brood per $A$. cerana colony is usually below 800 cells [30]. With $A$. cerana drone postcapping development times of 13.5-14 days $[39,43]$ a single fertile mite would have only approximately three to five reproductive cycles per year. This is a considerable limitation which imposes a strong selective pressure on $V$. jacobsoni to make a maximum reproductive effort within a limited period, and to endure the hosts' grooming efforts during enforced long phoretic periods with a reproductive diapause of up to 9 months [39].

The situation is different at the colony community level. In evergreen moist tropical habitats, drone brood production is not always restricted to a definite season. Within a local community of $A$. cerana colonies, drone brood may be present in single colonies and absent in others. For example, in the Suratani region of southern Thailand,

Table III. Reproducing V. jacobsoni in A. cerana worker and drone brood cells.

\begin{tabular}{lrrrrrrr}
\hline Cells inspected & \multicolumn{2}{c}{ Infested (\%) } & & \multicolumn{3}{c}{ Reproducing mites (\%) } \\
\cline { 2 - 3 } & Worker & Drone & & Worker & Drone & Worker & Drone \\
\cline { 6 - 8 } & 29740 & 927 & & $2.5 \%$ & $36.3 \%$ & $0 \%$ & $90.7 \%$ \\
Indonesia [1] & 2264 & 1266 & & $8-13 \%$ & $11-41 \%$ & $0 \%$ & $97-100 \%$ \\
Vietnam [5] & 2400 & 1600 & & $<1-8 \%$ & $0-60.5 \%$ & $0 \%$ & $100 \%$ \\
India [47] & 710 & 373 & & $4 \%$ & $20 \%$ & $0 \%$ & $90 \%$ \\
India [36] & 3500 & & $12.3 \%$ & & $1.8 \%$ & \\
Japan [39] & & & & &
\end{tabular}


A. cerana drone brood can be found in some colonies during any season, depending on the availability of local pollen resources. Sasaki [39] even found that $V$. jacobsoni propagates well in drone cells of queenless, laying worker colonies of $A$. cerana japonica, with four to five female offspring per mother mite. The important issue of mite dispersal among $A$. cerana colonies has not yet been studied. Furthermore, the influence of the absconding and migrating habits of $A$. cerana colonies on the $V$. jacobsoni population is uncertain. In some areas, such as northern Thailand, A. cerana bees migrate regularly during the dry and hot season.

Recent investigations of Boot et al. [5] on the reproductive biology of $V$. jacobsoni in A. cerana drone brood cells confirmed the hypothesis that $V$.jacobsoni face a natural selective pressure to maximize their reproductive effort within a short time. In comparison to A. mellifera hosts, the highest reproductive success of $V$. jacobsoni with respect to the number of offspring and the fertility of mites occurred in A. cerana drone cells. Boot et al. [5] found that $V$. jacobsoni females produce an average of 4.3 female offspring in A. cerana drone brood cells, and nearly $100 \%$ of the mites that entered drone cells actually reproduced. Table III compiles some comparative results from investigations on the reproductive rates of $V$. jacobsoni under natural conditions in four regions of Asia. The investigations reveal that $V$. jacobsoni do actually enter $A$. cerana worker cells but, apart from some exceptional cases, they do not reproduce $[5,11$, 47]. The invasion of worker brood cells is facilitated because the removal response of A. cerana bees is low if the mites originate from the very same colony [36].

\section{PHYSIOLOGICAL ASPECTS}

Boot et al. [5] posed the question as to why $V$. jacobsoni enter the worker brood cells of $A$. cerana if they do not reproduce there at all? These researchers assumed that the invasion A. cerana worker cells is an adaptive trait and that $V$. jacobsoni gain some prospective advantage from this behaviour. This advantage might be physiological preparation for postponed reproduction, or the avoidance of the grooming behaviour by adult bees. The cause of $V$. jacobsoni infertility in A. cerana worker cells is not known. The mites encounter a physiological barrier against reproduction on A. cerana worker brood. V. jacobsoni females that were transferred after initially feeding on A. mellifera brood to A. cerana worker brood continued to reproduce $[5,30$, 47]. This observation supports the hypothesis that $V$. jacobsoni females receive a certain nutritional trigger prior to oogenesis and reproduction [35].

$V$. jacobsoni have a very short period of ontogenesis which seems to be well synchronized with the host [13]. The rapid ontogenesis is supported by the very efficient exploitation of the host haemolymph proteins. $V$. jacobsoni have almost no proteolytic enzymes and utilize the host proteins immediately without prior digestion [45]. Tewarson et al. [44] provided evidence that reproducing $V$. jacobsoni incorporate the host proteins (A. mellifera) directly into the oocytes. According to Tewarson and Jany [46], this type of vitellogenesis is an indication of the high degree of parasitic adaptation which enables the mites to have very rapid oogenesis and a subsequent increase in reproduction efficiency. An additional feature of the accelerated ontogenesis of $V$. jacobsoni is the phenomenon of larviposition (ovoviviparity). The 'egg' that $V$.jacobsoni females deposit consists of an egg chorion containing a larva which transforms into a protonymph before hatching from the egg chorion [13]. Also, the protonymphae of $V$. jacobsoni directly utilize undegraded host proteins [45]. The physiological adaptation of $V$. jacobsoni to the utilization of undegraded host haemolymph components may partially account for the reproductive efficiency on other hosts besides the $A$. cerana drone larvae on which the natural selection 
for this adaptation took place. The fertility of $V$. jacobsoni on the acquired host, A. mellifera, is highly variable, depending on the genetics of the mites and bees and the local conditions $[1,2,3,10,16]$. Recent investigations on the mitochondrial DNA sequence of different $V$. jacobsoni populations [2, 3] indicate that $V$. jacobsoni is probably a "species-complex of at least three different species" [2] with significant differences in their reproductive performance on $A$. cerana or $A$. mellifera hosts. However, the highest fertility rates were reported from $A$. cerana drone hosts (table III). V. jacobsoni enter worker brood cells of $A$. cerana and occasionally begin reproductive efforts, but successful reproduction leading to fertile female adult offspring has rarely been observed in natural conditions $[10,35,47]$. It is likely that only specific components of the host haemolymph, which are best provided in A. cerana drones, ensure optimum fertility in $V$. jacobsoni. Tewarson and Engels [44] revealed that $V$. jacobsoni even utilize undegraded bovine serum albumen; however, the further effects of atypical host protein components on the reproduction biology of $V$. jacobsoni have not been investigated.

\section{PERSPECTIVES}

The co-adaptations of $V$. jacobsoni and A. cerana constitute a complex network of traits that support a dynamic balance between the host and the parasite populations. According to field observations [33] and model calculations $[16,25] V$. jacobsoni populations in $A$. cerana colonies are limited to numbers of less than approximately 800 mites per colony.

The early research reports overstated the significance of grooming and brood removal as the major mechanisms that define the resistance of $A$. cerana. Recent investigations, however, indicate that entombing, in combination with the population dynamics of $A$. cerana drone brood and physiologi- cal characteristics, may be of foremost importance in the tolerance of $A$. cerana to the mite. The recent discovery of distinct genotypes and biotypes in $V$. jacobsoni populations on $A$. cerana and $A$. mellifera hosts $[2,3]$ will require a re-interpretation of the virulence of $V$. jacobsoni on the acquired A. mellifera host. Furthermore, it has become clear that basic data is missing on the neurobiology of bees and mites. In particular, the investigation of the physiological background of the reproductive barriers of $V$. jacobsoni on A. cerana worker brood has the potential to open new approaches for the future search of $V$. jacobsoni tolerance in A. mellifera.

\section{Résumé - La coadaptation d'Apis cerana} Fabr. et de Varroa jacobsoni Oud. On peut considérer comme équilibrée la relation hôte-parasite entre l'abeille mellifère asiatique, Apis cerana, et l'acarien ectoparasite, Varroa jacobsoni : les abeilles limitent activement les populations d'acariens à un niveau supportable et la survie de l'acarien n'est pas mise en danger. Cet équilibre bien réglé est les résultats d'un long processus de coévolution au cours duquel les hôtes et les parasites ont développé des caractères spécifiques qui améliorent leur valeur adaptative respective. On résume ici divers aspects des caractères coadaptatifs, qui ont été étudiés durant les 20 dernières années, afin de faciliter l'interprétation de la relation hôte-parasite. On peut regrouper les caractères coadaptatifs en trois grandes catégories : i) les aspects comportementaux : caractères hygiéniques vs. caractères d'infestation, ii) les aspects de dynamique des populations, et iii) les aspects physiologiques. L'efficacité hygiénique d'A. cerana dépend des capacités sensorielles spécifiques et d'un ensemble correspondant de caractéristiques comportementales bien différenciées : toilettage, désoperculation des cellules et élimination du couvain infesté et « mise en bière » du couvain de mâles mortellement infesté. Les mâles parasités à de 
faibles niveaux d'infestation meurent dans leur cellule car ils sont incapables d'ouvrir le dur opercule de celle-ci. On peut déduire de divers travaux que la mise en bière du couvain hyperparasité réduit de plus de $20 \%$ la population d'acariens susceptibles de se reproduire. La mise en bière a été peu reconnue par les projets de recherche, mais elle contribue probablement de façon la plus efficace à limiter la croissance des populations de $V$. jacobsoni. Les capacités d'infestation de $V$. jacobsoni nécessitent des facultés sensorielles spécifiques pour localiser et différencier les divers stades de l'abeille adulte et du couvain. La contre-mesure la plus évidente contre le toilettage des abeilles est la protection offerte par la morphologie convexe-concave particulière de $V$. jacobsoni. À côté de ces adaptations morphologiques typiques des Varroidae, les acariens contrecarrent l'activité hygiénique collective des abeilles par des comportements spécifiques qui leur assurent la sécurité de la phorésie et de l'invasion des cellules de couvain, la survie à une longue diapause de la reproduction et le succès de la dispersion à d'autres colonies hôtes. Le comportement des hôtes et les barrières physiologiques limitent la reproduction du parasite à l'infestation du couvain de mâles. Cette restriction est un facteur-clé, puisque le couvain de mâles n'apparaît qu'à certaines périodes limitées dans le temps. Sous la pression de sélection $V$. jacobsoni doit survivre jusqu'à neuf mois par phorésie sur les ouvrières et atteindre une performance optimale de reproduction durant la période limitée d'accès au couvain de mâles. Des analyses génétiques ont récemment montré que $V$. jacobsoni pourrait être un complexe d'espèces constitué de groupes génétiquement distincts avec des différences de fertilité sur l'hôte Apis mellifera. Pourtant, même en comparant avec la situation sur l'hôte acquis $A$. mellifera, $V$. jacobsoni a la fertilité la plus forte et les taux de reproduction les plus élevés sur les mâles d' A. cerana. Les caractéristiques des barrières physiologiques qui empêchent le parasite de se reproduire sur le couvain d'ouvrières n'ont pas été étudiées. Le caractère unique, qui consiste à ingérer des protéines de l'hôte non digérées et à les utiliser immédiatement pour sa propre vitellogenèse, pourrait jouer un rôle dans l'établissement d'une barrière physiologique de la fertilité. L'utilisation de protéines de l'hôte non digérées fait partie de l'adaptation de $V$. jacobsoni à une ontogenèse raccourcie et une synchronisation ultérieure avec la métamorphose de l'hôte. La compréhension de l'équilibre hôte naturel-parasite entre $V$. jacobsoni et $A$. cerana est une condition préalable à de nouvelles approches dans la recherche de la tolérance d'A. mellifera à $V$. jacobsoni. Les processus de coadaptation physiologique et sensorielle entre $V$. jacobsoni et $A$. cerana sont très peu étudiés et font actuellement partie des domaines de recherche les plus prometteurs. (C) Inra/DIB/AGIB/Elsevier, Paris

\section{Apis cerana / Varroa jacobsoni / coadaptation}

\section{Zusammenfassung - Gegenseitige Anpas-} sung von Apis cerana Fabr. und Varroa jacobsoni Oud. Die Wirt-Parasitbeziehung zwischen der asiatischen Honigbiene Apis cerana Fabr. und der ektoparasitischen Milbe Varroa jacobsoni Oud. kann als balanciert betrachtet werden. Dies heißt, $\mathrm{d} a \beta$ die Honigbienen die Milbenpopulation aktiv auf eine erträgliche Höhe begrenzen und gleichzeitig das Überleben der parasitischen Milbenart nicht gefährdet ist. Dieses fein abgestimmte Gleichgewicht ist das Resultat eines über eine lange Zeitdauer zurückreichenden Prozesses gegenseitiger Anpassung, in dem sowohl Wirt als auch Parasit spezifische Eigenschaften entwickelt, die ihre jeweilige Fitness optimieren. Über die vergangenen 20 Jahre wurden unterschiedliche Aspekte dieser koadaptiven Eigenschaften untersucht, diese werden hier zusammenfassend dargestellt, um die Interpretation der Wirt-Parasitbeziehung zu erleichtern. Diese koadaptiven Eigenschaften können in drei Hauptkategorien zusam- 
mengefa $\beta t$ werden: 1) hygienische Eigenschaften vs. Befallsverhalten; 2) populations-dynamische Aspekte; und 3) physiologische Aspekte. Die hygienische Effizienz von $A$. cerana hängt von spezifischen sensorischen Fähigkeiten ab sowie korrespondierender gut definierter Verhaltenseigenschaften; Putzen, Entdeckeln von Zellen und Entfernen befallener Brut und das Einsargen von tödlich parasitierter Drohnenbrut. Die parasitierten Drohnen sterben bereits bei niedriger Parasitierung in ihren Brutzellen, da sie selbst nicht in der Lage sind, die harten Drohnendeckel zu öffnen. Aus verschiedenen Untersuchungen kann abgeleitet werden, da $\beta$ das Einsargen überparasitierter Drohnenbrut die vermehrungsfähige Milbenpopulation um mehr als $20 \%$ mindert. Das Einsargen wird in Forschungsprojekten nur wenig zur Kenntnis genommen, wahrscheinlich leistet es aber den effektivsten Beitrag zur Begrenzung der Population von $V$. jacobsoni. Die Fähigkeit zum Befallen von Brutzellen setzt besondere Sinnesleistungen voraus, um zwischen den Stadien ausgewachsener Bienen und denen der Bienenbrut unterscheiden zu können. Die offensichtlichste Gegenanpassung von $V$. jacobsoni gegen das Putzverhalten der Bienen ist der Schutz, den die eigentümliche konvex-konkave Körperform der Milben gewährt. Neben den typischen morphologischen Anpassungen der Varroidae setzen die Milben den kollektiven hygienischen Maßnahmen der Bienen spezifische Verhaltensweisen entgegen, die einen sicheren Aufenthalt auf den Arbeiterinnen, sichere Passage in die Brutzellen, das Überleben einer langen reproduktiven Diapause und erfolgreiche Verbreitung zu anderen Wirtsvölkern gewährleisten. Das Verhalten des Wirtes und physiologische Barrieren begrenzen die Vermehrung der Milben auf den Befall von Drohnenbrutzellen. Diese Einschränkung stellt einen Schliisselfaktor dar, da die Drohnenbrut nur während begrenzter Zeiträume zur Verfügung steht. So steht $V$. jacobsoni unter dem Anpassungsdruck, bis zu neun Monate lang pho- retisch auf den Arbeiterinnen überleben zu können. Darauf folgend muß sie während der kurzen Zeiten, in denen ihr der Zugang zur Drohnenbrut offensteht, eine optimale Vermehrungsleistung erbringen. Dementsprechend hat $V$. jacobsoni sogar im Vergleich mit der Situation auf dem angenommenen Wirt A. mellifera in Drohnenzellen von A. cerana die höchsten Fruchtbarkeits und Vermehrungsraten. Die Art der physiologischen Begrenzung, die $V$. jacobsoni davon abhält sich in den Arbeiterinnenzellen von $A$. cerana zu vermehren, wurden bisher allerdings nicht untersucht. Die besondere Eigenart, unverdaute Proteine aufzunehmen und sofort in der Dotterbildung weiter zu verwenden, könnte bei der Ausbildung einer physiologischen Barriere eine Rolle spielen. Der Gebrauch unverdauter Proteine stellt einen Teil der Anpassung von $V$. jacobsoni an den nur kurzen für die Entwicklung zur Verfügung stehenden Zeitraum und die daraus folgende Synchronisierung mit der Umwandlung des Wirtes dar. Das Verständnis des natürlichen Wirt-Parasitgleichgewichts zwischen $A$. cerana und $V$. jacobsoni ist eine Voraussetzung neuer Ansätze in der Suche nach Toleranz gegenüber der Milbe bei $A$. mellifera. Die physiologischen und sensorischen Koadaptationen zwischen $A$. cerana und $V$. jacobsoni sind nur wenig erforscht und stellen zur Zeit das vielversprechendste Forschungsgebiet in diesem Bereich dar. (C) Inra/DIB/AGIB/ Elsevier, Paris

\section{Apis cerana / Varroa jacobsoni / Anpassung / Koadaptation}

\section{REFERENCES}

[1] Anderson D.L., Changed Varroa jacobsoni reproduction in Apis mellifera colonies in Java, Apidologie 27 (1996) 461-466.

12] Anderson D.L., Genetic and reproductive variation in Varroa jacobsoni. in: Schwarz M.P., Hogendoorn K. (Eds.), Proceedings of the XIII International Congress of IUSSI, Adelaide, Australia, 29 December 1998-3 January 1999. Flinders University Press, Adelaide, 1998, pp. 33-33. 
[3] Anderson D.L., Fuchs S., Two genetically different populations of Varroa jacobsoni with contrasting reproductive abilities on Apis mellifera, J. Apic. Res. 37 (1998) 69-78.

[4] Boecking O., Rath W., Drescher W., Grooming and removal behaviour - strategies of Apis mellifera and Apis cerana bees against Varroa jacobsoni, Am. Bee J. 133 (1993) 117-1 19.

[5] Boot W.J., Tan N.O., Dien P.C., Huan L.V., Dung N.V., Long L.T., Beetsma J., Reproductive success of Varroa jacobsoni in brood of its original host, Apis cerana in comparison to that of its new host, Apis mellifera (Hymenoptera: Apidae), Bull. Entomol. Res. 87 (1997) 119-126.

[6] Bowen-Walker P.L., Martin S.J., Gunn A., Preferential distribution of the parasitic mite, Varroa jacobsoni Oud. on overwintering honeybee (Apis mellifera $\mathbf{L}$.) workers and changes in the level of parasitism, Parasitology 114 (1997) 151-157.

[7] Bruce W.A., Use of infrared detection for host location by the bee-mite, Varroa jacobsoni (Acari: Varroidae): a theroretical model, Int. J. Acarol. 23 (1997) 7-11.

[8] Bruce W.A., Delfinado-Baker M., Vincent D.L., Comparative morphology of the peritremes of Varroa and Euvarroa (Varroidae), parasites of honey bees (Apidac), Int. J. Acarol. 23 (1997) 13-20.

[9] Büchler R., Varroa tolerance in honeybees occurrence characters and breeding, in: Matheson A. (Ed.), New Perspectives on Varroa, International Bee Research Association, Cardiff, 1994, pp. 12-23.

[10] Büchler R., Drescher W., Tornier I., Grooming behaviour of Apis cerana, Apis mellifera, and Apis dorsata and its effect on the parasitic mites Varroa jacobsoni and Tropilaelaps clareae, Exp. Appl. Acarol. 16 (1992) 313-319.

[11] De Jong D., Varroa jacobsoni does reproduce in worker cells of Apis cerana in South Korea, Apidologie 19 (1988) 241-244.

[12] Delfinado-Baker M., Baker E., Phoon A.C.G., Mites associated with honeybees (Apidae) in Asia with description of a new species, Am. Bee J. 129 (1989) 609-613.

[13] Delfinado-Baker M., Peng C.Y.S., Varroa jacobsoni and Tropilaelaps clareae: A perspective of life history and why Asian bee-mites preferred European honeybees, Am. Bee J. 135 (1995) 415-420.

[14] Delfinado-Baker M., Rath W., Boecking O., The phoretic bee mites and honeybee grooming behaviour, Int. J. Acarol. 18 (1992) 315-322.

[15] Donzé G., Guerin P.M., Behavioral attributes and parental cale of Varroa jacobsoni mites parasitizing honeybee brood, Behav. Ecol. Sociobiol. 34 (1994) 305-319.

[16] Fries I., Camazine S., Sneyd J., Population dynamics of Varroa jacobsoni: a model and review, Bee World 75 (1994) 5-28.
[17] Fries I, Huazhen W., Wei S., Jin C.S., Grooming behaviour and damaged mites (Varroa jacobsoni) in Apis cerana cerana and Apis mellifera ligustica, Apidologie (1996) 3-11.

[18] Fuchs S., Langenbach K., Multiple infestation of Apis mellifera L. brood cells and reproduction in Varroa jacobsoni Oud., Apidologie 20 (1989) 257-266.

[19] Hadisoesilo S., Otis G. W., Differences in the drone cappings of Apis cerana F., 1793 and Apis nigrocincta Smith 1861, J. Apic. Res. (1998) in press.

[20] Hänel H., Ruttner F., The origin of the pore in the drone cell capping of Apis cerana Fabr., Apidologie 16 (1985) 157-164.

[21] Koeniger N., Koeniger G., Wijayagunasekara N.H.P., Beobachtungen über die Anpassungen von Varroa jacobsoni an ihren natuerlichen Wirt Apis cerana in Sri Lanka, Apidologie 12 (1981) 37-40.

[22] Koeniger N., Koeniger G., Delfinado-Baker M., Observations on mites of the Asian honeybee species, Apidologie 14 (1983) 197-204.

[23] Koeniger N., Koeniger G., Mardan M., Wongsiri S., Possible effects of regular treatments of varroatosis on the host-parasite relationship between Apis mellifera and Varroa jacobsoni, in: Conner L.J., Rinderer T., Sylvester H.A., Wongsiri S. (Eds.), Asian Apiculture, Wicwas Press, Cheshire, CT, 1993, pp. 54I-550.

[24] Kraus B., Koeniger N., Fuchs S., Unterscheidung zwischen Bienen verschiedenen Alters durch Varroa jacobsoni und Bevorzugung von Ammenbienen im Sommerbienenvolk, Apidologie 17 (1986) 257-266.

[25] Martin S.J., Life and death of Varroa, in: Munn P. (Ed.), Fight the Mite, International Bee Research Association, Cardiff, UK, 1997, pp. 3-10.

[26] Milani N., Analytical bibliography on Varroa jacobsoni Oud. and related species, Apicoltura 8 (1994) 1-147.

[27] Nation J.L., Sanford M.T., Milne K., Comparison of cuticular hydrocarbons from varroa mites and honeybees, Am. Bee J. 131 (1991) 778-779.

[28] Peng Y.S., Fang Y., Xu S., Ge L., The resistance mechanism of the Asian honey bee Apis cerana Fabr., to an ectoparasitic mite Varroa jacobsoni Oudemans, J. Invertebr. Pathol. 49 (1987) 54-60.

[29] Peng Y.S., Fang Y., Xu S., Ge L., Nasr M., Response of foster Asian honeybee (Apis cerana Fabr.) to the brood of European honeybee (Apis mellifera L.) infested with parasitic mite, Varroa jacobsoni Oudemans, J. Invertebr. Pathol. 49 (1987).

[30] Rath W., Investigations on the parasitic mites Varroa jacobsoni Oud. and Tropilaelaps clareae Delfinado \& Baker and their hosts Apis cerana Fabr. Apis dorsata Fabr. and Apis mellifera L., Dissertation, Rheinischen Friedrich Wilhelms Universität Bonn, 1991. 
131] Rath W., The key to Varroa: The drones of Apis cerana and their cell cap, Am. Bee J. 132 (1992) 329-331.

[32] Rath W., Aspects of pre-adaptation in Varroa jacobsomi while shifting from its original host Apis cerana to Apis mellifera, in: Conner L.J., Rinderer T., Sylvester H.A., Wongsiri S. (Eds.), Asian Apiculture, Wicwas Press, Cheshire, CT, 1993, pp. 417-426.

[33] Rath W., Drescher W., Response of Apis cerana Fabr. towards brood infested with Varroa jacobsoni Oud. and infestation rate of colonies in Thailand, Apidologie 21 (1990) 311-321.

[34] Ridley M., Evolution, Blackwell Science, Cambridge, MA, 1996.

[35] Rosenkranz P., Tewarson N.C., Rachinsky A., Strambi A., Strambi C., Engels W., Juvenile Hormone titer and reproduction of Varroa jacobsoni in capped brood stages of Apis cerana indica in comparison to Apis mellifera ligustica, Apidologie 24 (1993) 375-382.

[36] Rosenkranz P., Tewarson N.C., Singh A., Engels W., Differential hygienic behaviour towards Varroa jacobsoni in capped worker brood of Apis cerana depends on alien scent adhering to the mites, J. Apic. Res. 32 (1993) 89-93.

[37] Rothenbuhler W., Behaviour genetics of nest cleaning behaviour in honeybees. I. Response of four inbred lines to disease killed brood, Anim. Behav. 12 (1964) 578-583.

[38] Ruttner F., Biogeography and Taxonomy of Honeybees, Springer, Berlin, 1988.

[39] Sasaki M., The reason why Apis cerana japonica is resistant to Varroa mite, Honeybee Sci. 10 (1989) 28-36 (in Japanese)

[40] Schulz-Langer E., Zum Verhalten der Honigbiene beim Säubern von Zellen mit faulbruterkrankten Larven, Z. Bienenforsch. 5 (1960) 1-7.

[41] Spivak M., Honey bee hygienic behaviour and defense against Varroa jacobsoni, Apidologie 27 (1996) 245-260.
[42] Spivak M., Gilliam M., Facultative expression of hygienic behaviour of honey bees in relation to disease resistance, J. Apic. Res. 32 (1993) 147-157.

[43] Tan N.Q., Huan L.V., Dung N.V., Development time of eggs, open brood and capped brood of Apis cerana and Apis mellifera in southern Vietnam. in: Connor L.J., Rinderer T., Sylvester H.A., Wongsiri S. (Eds.), Asian Apiculture, Wicwas Press, Cheshire, CT, 1993, pp. 243-247.

[44] Tewarson N.C., Immunocytochemical localization of host (Apis mellifera) proteins in growing oocytes of a haemophagous mite (Varroa jacobsoni ) by the unlabeled antibody-enzyme (PAP) method, J. Invertebr. Reprod. 5 ( 1982 ) 345-348.

[45] Tewarson N.C., Engels, W., Undigested uptake of non-host proteins by Varroa jacobsoni, J. Apic. Res. 21 (1982) 222-225.

[46] Tewarson N.C., Jany K., Determination of proteolytic activity in Varroa jacobsoni an ectoparasitic haemophagous mite of honeybees (Apis sp.), Apidologie 13 (1982) 383-389.

[47] Tewarson N.C., Singh A., Engels, W., Reproduction of Varroa jacobsoni in colonies of Apis cerana indica under natural and experimental conditions, Apidologie 23 (1992) 161-171

[48] Trouiller J., Arnold G., Le Conte Y., Masson C., The production of kairomones of Varroa jacobsoni and brood pheromones by honey bee larvae, in: Connor L.J., Rinderer T., Sylvester H.A., Wongsiri S. (Eds.), Asian Apiculture, Wicwas Press, Cheshire, CT, 1993, pp. 447-453.

[49] Wongsiri S., Tangkanasing P., Sylvester H.A., The resistance behaviour of Apis cerana against Tropilaelaps clareae, in: Wongsiri S., Rinderer T.E., Sylvester H.A. (Eds.), Biodiversity of Honeybees in Thailand, BBRU Chulalongkorn University, Bangkok, 199 1, pp. 25-34 